\title{
Use of Propranolol in Infantile Hemangioma Resulting in Scarless Healing
}

\author{
Rachel Vania, Denny Irwansyah \\ Department of Plastic Surgery, Gatot Subroto Central Army Hospital, Jakarta, Indonesia
}

\begin{abstract}
Abstrak
Infantile hemangiomas (IHs) are the most common childhood tumors. Some can ulcerate causing pain, bleeding, and scarring, leading to cosmetical disfigurement. The use of propranolol has beaten the traditional high-dose systemic corticosteroids therapy, which falls short on its infamous adverse effects. In these case series, regimen of propranolol was highlighted when surgery is not an option. Two cases were presented. Case 1 involveda threemonth-old baby girl was presented with a $0.6 \times 0.6 \mathrm{~cm}$ disfiguring purple tumor on her nasal tip and columella and Case 2 involveda three-month-old baby girl with a $2 \times 0.5 \mathrm{~cm}$ sharply bordered and bulging red tumor on her left labium major.Both lesions became visible at the age of 3 months and grew rapidly since then. Propranolol was initiated at $2 \mathrm{mg} / \mathrm{kgBW}$ per day with careful administration. Adverse effects and drug tolerance were closely monitored under pediatrician and plastic surgery care with none reported. Dramatic results was seen after 2 weeks of treatment and no scar was found at the end of the therapy. This confirmed that propranolol is an effective and well tolerated treatment when commenced early and continued with the minimum protocol of $2 \mathrm{mg} / \mathrm{kgBW} /$ day through the proliferative phase of infantile hemangioma. It is concluded that propranolol is beneficial for managing infantile hemagioma cases with a scarless outcome that cannot be achieved through surgery. The use of propanolol is extremely beneficial when the case involves a tumor in a site that makes it impossible for reconstruction.
\end{abstract}

Key words: Hemangioma, infant, newborn, propranolol

\section{Penggunaan Propranolol pada Hemangioma Infantil yang Menghasilkan Penyembuhan Tanpa Bekas Luka}

\begin{abstract}
Hemangioma infantil adalah tumor yang paling sering pada anak. Tumor ini dapat mengalami ulserasi, nyeri, perdarahan, parut buruk, sampai menyebabkan penampilan cacat. Terapi propranolol telah mengalahkan kortikosteroid, yang dikenal mempunyai banyak efek samping yang buruk. Pada serial kasus ini, kami akan menyoroti regimen penggunaan propranolol, ketika pembedahan tidak mungkin dilakukan. Kasus 1: Bayi perempuan, 3 bulan, datang dengan tumor keunguan yang menyebabkan disfigurasi pada nasal tip dan kolumela. Kasus 2: Bayi perempuan, 3 bulan, datang dengan tumor kemerahan, berbatas tegas dan benjol, pada labium mayor sinistra. Kedua lesi timbul pada usia 3 bulan dan membesar dalam hitungan hari. Propranolol dimulai dengan dosis $2 \mathrm{mg} / \mathrm{kg} / \mathrm{BB}$ per hari, dengan pengawasan ketat oleh spesialis anak dan bedah plastik. Kedua kasus tidak terdapat efek samping dan toleransi obat baik. Hasil drastis terlihat dalam dua minggu dan pada akhir terapi didapatkan parut yang kasat mata. Kasus kami mengonfirmasi bahwa terapi propranolol adalah efektif dan dapat ditoleransi dengan baik, diberikan dini dan stabil pada dosis $2 \mathrm{mg} / \mathrm{kg} / \mathrm{BB}$ per hari pada fase proliferasi, dengan hasil tanpa bekas yang tidak dapat dicapai dengan pembedahan. Kami ingin meningkatkan kesadaran pada dokter dalam penggunaan propranolol yang telah dibuktikan bermanfaat, terutama pada tumor yang berada di tempat yang tidak dapat dioperasi dan sulit direkonstruksi.
\end{abstract}

Kata kunci: Bayi, hemangioma, neonatal, propranolol

Corresponding Author: Denny Irwansyah, Department of Plastic Surgery, Gatot Subroto Central Army Hospital, Jakarta, Jalan Abdul Rahman Saleh No. 24, Senen, Central Jakarta, DKI Jakarta 10410, Indonesia, Email: dennyirwansyah1976@yahoo.com 


\section{Introduction}

Infantile hemangiomas (IHs) are common benign tumors in infancy, composed of proliferating endothelial-like cells. ${ }^{1}$ The International Society for the Study of Vascular Anomalies (ISSVA) further discerns hyperplasia nature from vascular malformation, in which the former possesses hyperplastic nature, while the latter represents an irregular vascular network morphogenesis. ${ }^{2}$ Infantile Hemangiomas, the prototypical vascular tumor, present in weeks after birth and go through rapid proliferating phase over months before eventually slowing down and regressed in several years, unlike the opponent, which never regresses. ${ }^{3}$

Their prevalence has been estimated as $2-3 \%$ in the neonates, and found to be more frequent in girls than boys, ranging from a 3-5:1 ratio. ${ }^{4}$ Previously referred to as vascular birthmarks ${ }^{2}$, IHs prominently appear in any part of the body, most commonly are in the head and neck (60\%), the trunk (25\%) and the extremities (15\%). ${ }^{4}$

Although most of infantile hemangiomas resolve spontaneously without any needs for therapy; $10 \%$ can cause complication requiring intervention or management. ${ }^{3}$ The most common complication is ulceration, which can be disfiguring, dysfunctional, or worst, life threatening. ${ }^{5}$ Thus, the timely recognition and therapy are paramount to achieve minimal scarring and complication. ${ }^{5,6}$ Over the last few years, propranolol has gained popularity since was found accidentally while treating cardiovascular disease, ${ }^{7}$ and has been recommended as a first-line therapy in the management of proliferating IHs in some centers, especially when involving the airway. ${ }^{7,8,9}$ It may exert its effects on growing hemangiomas by three different molecular mechanisms: vasoconstriction, inhibition of angiogenesis, and induction of apoptosis, especially during hypoxia. $^{10}$

\section{Case Report -1}

A three-month-old baby girl was brought to a plastic surgery clinic in RSPAD Gatot Soebroto, Jakarta, on November $28^{\text {th }}, 2017$ by her mother.

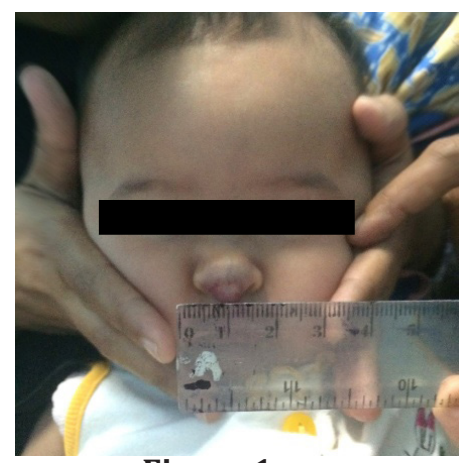

Figure 1a

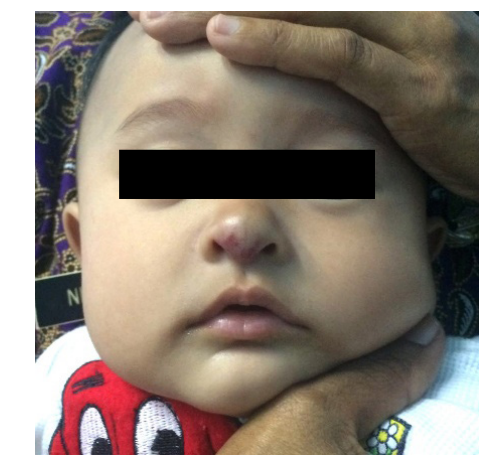

Figure 1b

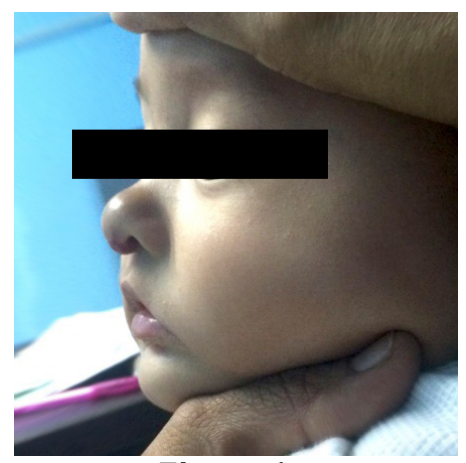

Figure 1c

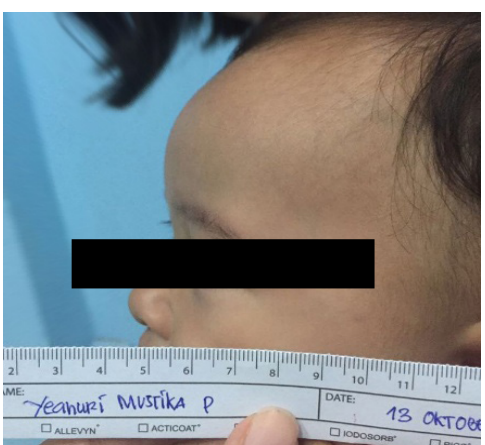

Figure 1d

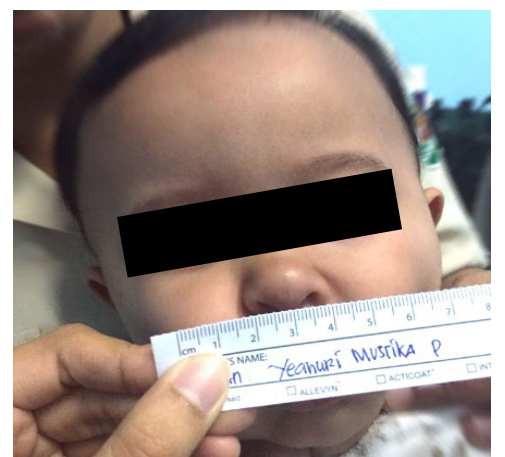

Figure 1e

Figure 1 Photographs of the Tumor on the Nasal Tip and Columella

a. The initial presentation: front view; b. Lateral view.; c. After 2 weeks of therapy; d. After 5 months of therapy: front view; e. The tumor was faintly seen: lateral view. 
She had a disfiguring purple tumor on her nasal tip and columella (Figure 1a). The lesion became visible at three months of age and grew rapidly ever since. It was sharply demarcated and measured $0.6 \times 0.6 \mathrm{~cm}$. Propranolol was initiated at a dosage of $3 \times 4 \mathrm{mg}$ per day. In the following 2 weeks, it had slightly decreased, although uneven discoloration was still noted (Figure 1b). After five months of therapy, it had been barely noticed, leaving a multiple purple spots on the columella (Figure 1c).

\section{Case Report-2}

A three-month-old baby girl attended the same clinic on December 2 $2^{\text {nd }}, 2017$ with a $2 \times 0.5 \mathrm{~cm}$ sharply bordered and bulging red irregular tumor on her left labium major (Figure 2a). It was not present at birth. Propranolol was initially administered at a dosage of $3 \times 4 \mathrm{mg}$ per day. The mother noticed the discoloration in the second treatment. Three months later, the scar had significantly faded and reduced in size (Figure 2b), and continued to cease on the $8^{\text {th }}$ month of therapy (Figure 2c).

Through the course of therapy, the dosage was adjusted in accordance with the weight gain. Adverse effect and drug tolerance were monitored closely by both pediatrician and plastic surgery. Potential side effects were informed to both parents. Blood glucose was examined regularly upon follow up; arrhythmia and increased airway resistance were also assessed. There was no adverse effect reported and found on both infants. The treatment was planned to be continued until the infants reach 1 year of age.

\section{Discussion}

Although many are resolved without sequel, any form of intervention is requisite for lesion in the face ${ }^{11}$. It is utmost important to consider the psychological as well as medical impact of IHs, because many facial lesions leave scars or structural deformities, and life-long impact. ${ }^{5}$ Prevention of life-threatening complications, prevention of permanent scarring/ disfigurement, and avoidance of aggressive treatments are the goals of management. ${ }^{11}$ The cells in IHs are different from normal endothelial cells. Their unique nature suggestively owes to a mutation in endothelial progenitor cells (EPCs). Propranolol apparently down-regulates proangiogenic cytokines in EPC trafficking. The vasoconstrictive effect, the suppression of endothelial growth factors, and the blockade of GLUT-1 receptors, might account for the involution. $^{10}$ Better understanding of the molecular pathology of vascular tumor gives aid to propranolol as a targeted therapy for IHs, but also requires timely management at the proliferating phase of IHs. In these cases, patients were brought at three months of age, which is the perfect time to impede the tumor proliferation.

The previous proposed empirical dosage among publications are varied from $1-3 \mathrm{mg} /$ BW/day administered with arrays of methods and durations. The effective dosage usually

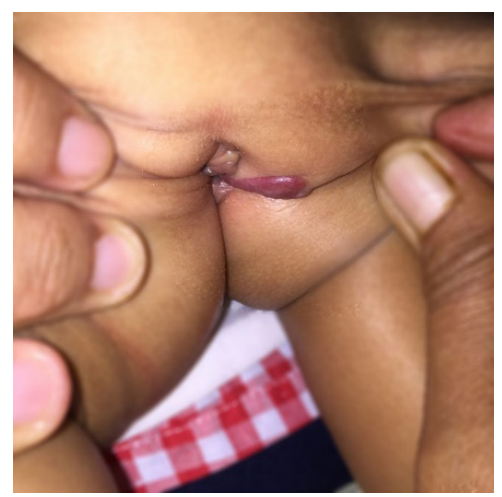

Figure 2a

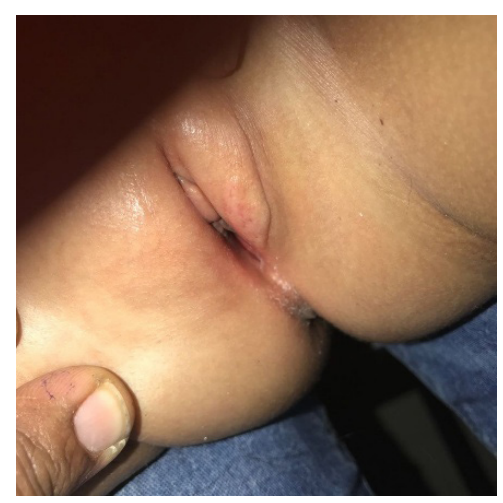

Figure 2b

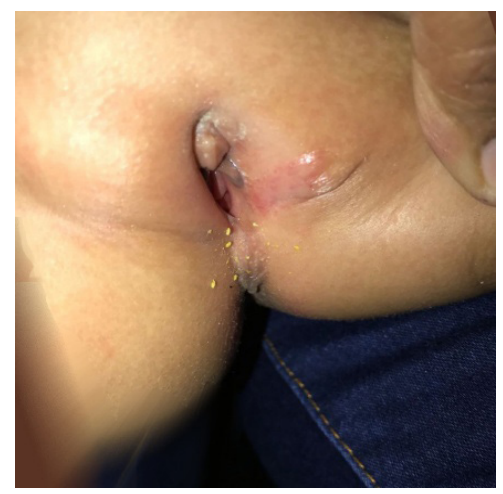

Figure 2c

Figure 2 Photographs of the Vascular Tumor on the Left Labium Major

A. The initial presentation; B. In the following 3 months, tumor was significantly reduced;C. 9 months of therapy, the end of proliferating phase 
used is $2 \mathrm{mg} / \mathrm{BW}$ daily in three divided doses, with treatment continued until the end of the proliferative phase, and weaning of propranolol over a 2-month period., ${ }^{3,9}$ Another study conducted by Szychta et al, found that daily dosage should be reevaluated frequently, related to age and weight gain in infants, although it should not fall below $2 \mathrm{mg} / \mathrm{BW} /$ day. $^{8}$ In these cases, the tumor was responsive to the minimal dose of $2 \mathrm{mg} / \mathrm{BW} /$ day, and divided into 3 doses, which made the $3 \times 4 \mathrm{mg}$ dosage daily adjusted to the infants' weight gain.

Propranolol is generally a safe drug, but it has been associated with several adverse effects, including bradycardia, hypoglycemia, and hypotension. ${ }^{11}$ Other adverse effects include congestive heart failure, depression, nausea, vomiting, abdominal cramping, sleep disturbance, and night terrors; all of which are rarely seen at doses more than $2 \mathrm{mg} / \mathrm{BW}$. Children are most susceptible to hypoglycemia. $\beta$-blocker can mask the early sympathetic signs of hypoglycemia such as tachycardia, sweating, and palpitation. ${ }^{12}$ It is therefore advised to be temporarily discontinued for those with low birth weight, reduced calorie intake, or current illness. Parents should be instructed to ensure that their child is fed regularly and avoided prolonged fast. ${ }^{1}$ In this study, both patients were informed about the side effects of beta blocker and educated when to stop the treatment if the child was ill or not feeding well. We monitored the blood glucose level, pulse, and other vital signs, and found no signs of complications of the treatment.

Another careful utilization of propranolol includes agradual tapering off over a period of 2 months $^{3}$, which minimizes the risk of rebound growth and hyperadrenergic withdrawal response $^{8}$. It is usually weaned after 6 months of treatment, when the tumor reaches the end of proliferative phase.

In conclusions, to treat the head and neck hemangiomas of infantile, highly experienced and vigilant judgment of a plastic surgeon is essential. The major reason is that certain subunits such as nose (tip of the nose, columella, etc) are utterly important and irreplaceable to reconstruct, therefore, non-surgical treatments like propranolol are chosen. Results obtained from this study confirmed that propranolol is an effective and well tolerated treatment, commenced early and continued with the minimum protocol of $2 \mathrm{mg} / \mathrm{BW} /$ day. In the end, the results be obtained without scars, which cannot be compared with surgical treatment.

Plastic surgeons must be able to predict not only side effects in every difficult situation, but also take actions that lead to the best results. It is better not to rush to hold a blade to remove certain tumors and make unnecessary scars.

\section{References}

1. Drolet BA, Frommelt PC, Chamlin SL, Haggstrom A, Bauman NM, Chiu YE, et al. Initiation and use of propranolol for infantile hemangioma: report of a consensus conference. Pediatrics. 2013;131(1):128-40.

2. Richter TG and Friedman AB. Hemangiomas and vascular malformations: current theory and management. Int J Pediatr. 2012;2012:645678.

3. Chim H, Gosain AK. Vascular Anomalies. In, Chung KC, Gosain AK, Gurtner GC, Mehrara JB, Rubin JP, Spear SL, editor. Grabb and Smith's plastic surgery. $7^{\text {th }}$ ed. Philladelphia: Lippincott Williams \& Wilkins; 2013. p. 20613.

4. Zheng JW, Zhang L, Zhou Q, Mai HM, Wang YA, Fan XD, et al. A practical guide to treatment of infantile hemangiomas of the head and neck. IInt J Clin Exp Med. 2013;6(10):851-60.

5. Chen TS, Eichenfield LF, Friedlander SF. Infantile hemangiomas: an update of pathogenesis and therapy. Pediatrics. 2013; 131(1):99-108.

6. Shayan YR, Prendiville JS, Goldman RD. Use of propranolol in treating hemangiomas. Can Fam Physician. 2011;57(3):302-3.

7. Natawidjaja $R$, Wang E. Treatment of complex infantile haemangioma in a resource-poor setting. BMJ Case Rep. 2014; 2014:bcr2014205330.

8. Szychta P, Stewart K, Anderson W. Treatment of infantile hemangiomas with propranolol: clinical guidelines. Plast Reconstr Surg. 2014;133(4): 852-62.

9. Pacifici GM. Treatment of infantile hemangioma with propranolol. Medical express. 2014;1(6):323-7.

10. Kleinman ME, Greives MR, Churgin SS, Blechman KM, Chang EI, et al. Hypoxiainduced mediators of stem/progenitor cell trafficking are increased in children with hemangioma. Arterioscler Thromb Vasc Biol. 2007;27(12):2664-70.

11. Gunturi N, Ramgopal S, Balagopal S, Scott JX. Propranolol therapy for infantile 
hemangioma. Indian Pediatr. 2013;50(3): 307-13.

12. Holland KE, Frieden IJ, Frommelt PC, Mancini AJ, Wyatt D, Drolet BA. Hypoglycemia in children taking propranolol for the treatment of infantile hemangioma. Arch Dermatol. 2010;146(7):775-8. 